\title{
Editorial
}

\section{Front-of-package nutrition labelling policy: global progress and future directions}

First published online 21 March 2018

Nutrition labelling on food packages has been voluntarily implemented by food companies since the beginning of the 20th century. By the end of the 20th century, both governments and non-governmental organizations began to implement different front-of-package (FOP) nutrition labelling systems. FOP nutrition labels encompass a specific element of nutrition labelling postulated to allow for quick decision making about the nutritional content or relative healthfulness of a product provided through its simple, easily viewable and interpretable format ${ }^{(1,2)}$. The policy objectives of FOP nutrition labelling are typically twofold: (i) to provide additional information to consumers to inform healthier food choices; and (ii) to encourage the industry to reformulate products towards healthier options. Recent reviews have summarized the implementation of nutrition labelling policies in general $^{(3,4)}$. However, there has been an exponential rise in both government and private-sector FOP nutrition labelling policy that deserves specific attention ${ }^{(5,6)}$.

While it has been argued that FOP nutrition labelling is a marketing, rather than a public health strategy $^{(7)}$, the purpose of this editorial is to provide an update on the global policy environment regarding governmentendorsed FOP nutrition labelling and to examine realworld evidence of policy implementation.

\section{Notable global policy action}

With the start of the 21st century, concomitant with the emerging global obesity epidemic and the greater abundance of ultra-processed foods in the marketplace ${ }^{(8,9)}$, the number of both public and private FOP nutrition labelling initiatives has increased steadily ${ }^{(10)}$ (see Fig. 1 for a timeline of FOP policy implementation globally).

The WHO first proposed FOP nutrition labelling as a policy measure to improve diet and health in $2004^{(11)}$. Thereafter, the WHO has repeatedly sought to promote FOP nutrition labelling as part of a comprehensive policy response to the global epidemic of obesity and diet-related non-communicable diseases, including through the Global Action Plan for the Prevention and Control of Noncommunicable Diseases, the Commission on Ending Childhood Obesity, and specific FOP nutrition labelling workshops $^{(12-15)}$. In 2012, the Institute of Medicine (now the National Academy of Medicine) published a comprehensive review on FOP nutrition labelling that issued the following recommendations regarding any FOP nutrition labelling evaluation scheme: (i) allow only four items (energy (calories), saturated fat, trans-fat, sodium, sugars); and (ii) keep the format simple, easy to interpret, integrated with other nutrition information and supported by communication $^{(16)}$. In contrast, the WHO's recommendations regarding FOP nutrition labelling are not specific regarding format, content and criteria of such labelling. Thus, unlike for backof-package nutrition information panels and ingredients lists, there is currently no explicit international agreement for national mandatory FOP nutrition labelling in the current standards of the Codex Alimentarius Commission ${ }^{(17)}$.

The development of such a standard, however, is now under formal consideration by the Codex Committee on Food Labelling ${ }^{(18)}$. This is important as the World Trade Organization considers Codex standards when resolving trade disputes between states. Nutrition labelling requirements have been cited as 'technical barriers' to the trade of packaged food products across borders. For example, specific trade concerns have been raised at the World Trade Organization's Technical Barriers to Trade Committee regarding FOP nutrition labelling schemes in Thailand, Chile, Indonesia, Peru and Ecuador ${ }^{(19)}$. These concerns are related to the consistency of proposed policies with international standards (i.e. their deviation from Codex Alimentarius guidelines) and the justification of such policies, supported by scientific evidence of effectiveness of the specific systems proposed compared with alternative approaches that aim to improve population nutrition with less impact on trade ${ }^{(19)}$.

\section{Variation in front-of-package nutrition labelling schemes}

Worldwide, FOP nutrition labelling has been implemented through government policies in a myriad of ways utilizing different terminology (see Table 1 for a list of commonly used terms in the FOP literature). A summary of the various FOP nutrition labelling schemes introduced globally can be found in Table 2 .

FOP nutrition labelling schemes vary in presentation (e.g. shape, colour, size), type of public health nutrition message (proscriptive, prescriptive or both) and nutrient focus (e.g. focus on 'critical nutrients' or inclusion of both positive and negative nutrients). To date, the most common 'critical nutrients' that have been included in FOP nutrition labelling schemes are sodium, fats (saturated, trans) and total sugars, as recommended in the Institute of 


\section{Timeline}

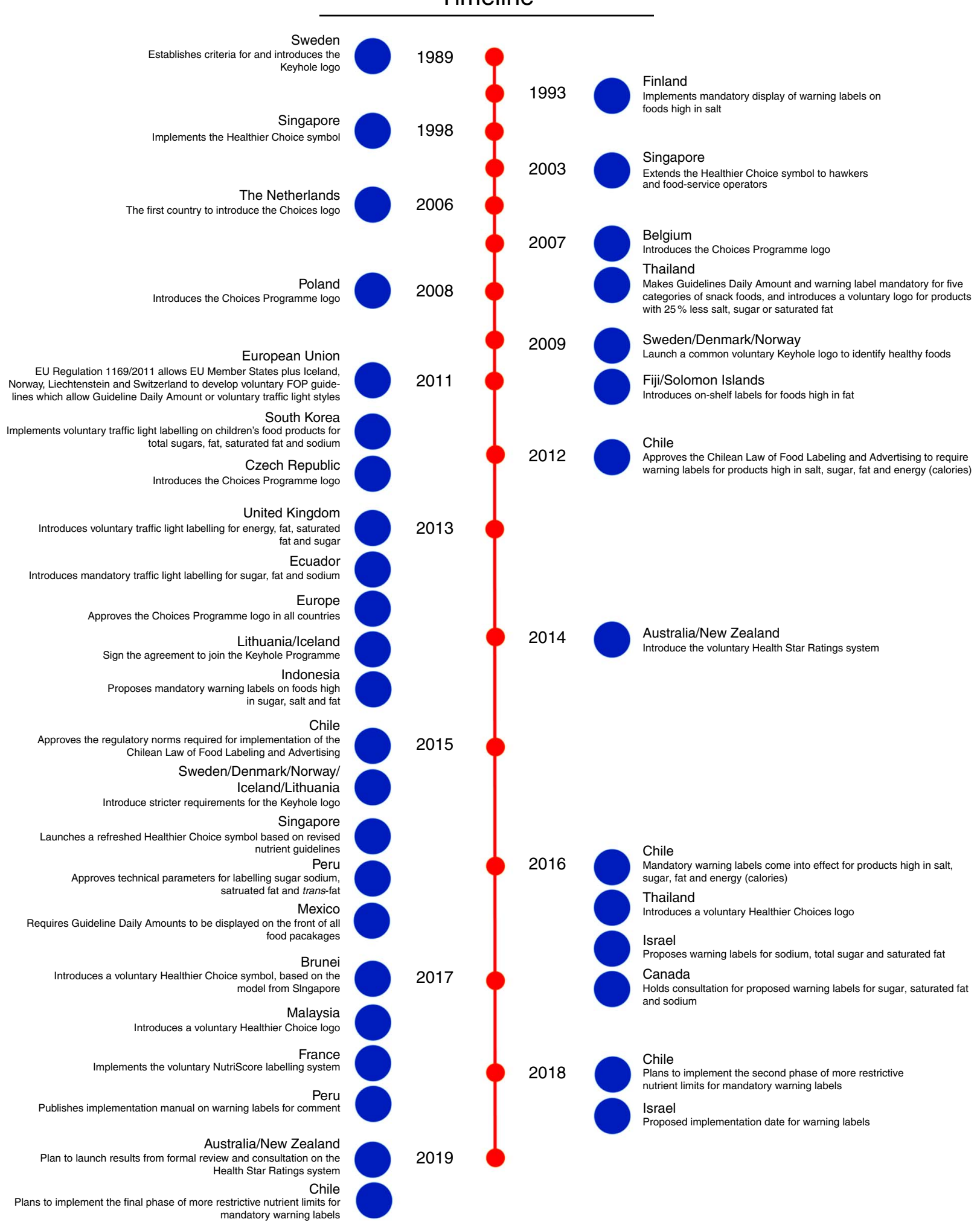

Fig. 1 (colour online) Timeline of front-of-package (FOP) nutrition labelling globally (adapted from the NOURISHING framework ${ }^{(6)}$ and other sources)

Medicine report ${ }^{(16)}$. Some, but not all, of the FOP nutrition labelling schemes also include certain nutrient-rich components, such as fibre, whole grains, protein and/or fruits and vegetables. Below is provided a summary of various government-led FOP nutrition labelling schemes that have been implemented, divided by type, and how they vary. 
Table 1 Terms used for various types of government-endorsed front-of-package nutrition labelling schemes

\begin{tabular}{|c|c|c|}
\hline Terminology & Definition (reference) & Examples \\
\hline $\begin{array}{l}\text { Interpretive } \\
\text { nutrition rating } \\
\text { system (INRS) }\end{array}$ & $\begin{array}{l}\text { Provides nutrition } \\
\text { information as guidance } \\
\text { rather than specific } \\
\text { facts }^{(16)}\end{array}$ & $\begin{array}{l}\text { - Star-based } \\
\text { systems } \\
\text { - Nutriscore } \\
\text { - Traffic light } \\
\text { symbols } \\
\text { - Health logos }\end{array}$ \\
\hline Reductive system & $\begin{array}{l}\text { Shows information only, } \\
\text { with no specific } \\
\text { judgement, opinion or } \\
\text { recommendation }^{(56)}\end{array}$ & $\begin{array}{l}\text { - Guideline Daily } \\
\text { Amount (GDA) } \\
\text { system }\end{array}$ \\
\hline $\begin{array}{l}\text { Evaluative/ } \\
\text { summary } \\
\text { indicator } \\
\text { system }\end{array}$ & $\begin{array}{l}\text { Combines several criteria to } \\
\text { establish one indication } \\
\text { of the healthiness of a } \\
\text { product and shows } \\
\text { judgement, opinion or } \\
\text { recommendation with no } \\
\text { specific information }^{(56)}\end{array}$ & $\begin{array}{l}\text { - Star-based } \\
\text { systems } \\
\text { - Health logos }\end{array}$ \\
\hline $\begin{array}{l}\text { Nutrient-specific } \\
\text { system }\end{array}$ & $\begin{array}{l}\text { Provides nutrition } \\
\text { information for a set of } \\
\text { nutrients }^{(10)}\end{array}$ & $\begin{array}{l}\text { - Traffic light } \\
\text { symbols } \\
\text { - Warnings or } \\
\text { 'High in' } \\
\text { symbols }\end{array}$ \\
\hline
\end{tabular}

\section{Health logos}

The first FOP nutrition labelling systems to be implemented were health logo systems. The Keyhole logo was the first logo system introduced in 1989, mainly in the Nordic European countries (Table 2). The Choices Programme logo is an international industry-led scheme that was later endorsed by some European governments. It was first introduced in the Netherlands in 2006, but received EU-wide approval in 2013. Several Asian countries based the development of their healthier choices logos on the Choices International system ${ }^{(20)}$. Unlike other systems, the Choices Programme includes trans-fatty acids and added sugar within its criteria. In some countries, such as Brunei, manufacturers must supply a food analysis report from an accredited food laboratory to the Choices Programme Committee before they can use the logo on their products. While logos have been widely introduced in a range of countries (Table 2), some research groups, like INFORMAS (International Network for Food and Obesity/non-communicable Diseases Research, Monitoring and Action Support), consider logos to be health claims rather than interpretive FOP nutrition labelling ${ }^{(21)}$.

\section{Traffic lights}

Traffic light FOP nutrition labelling is named as such because it uses the typical traffic light colours (green, yellow/amber, red) to denote prescriptive and proscriptive nutrient contents, respectively. Traffic light FOP nutrition labelling has been relatively less popular and has been introduced by only three countries (the UK, Ecuador and South Korea), only one of which is mandatory (Ecuador; Table 2). The UK and South Korean FOP nutrition labelling systems include both total and saturated fat, compared with Ecuador that only includes total fat. While voluntary, the limits for total fat are more restrictive in the UK than in Ecuador, while the opposite occurs for total sugars (Table 2). Some early results from Ecuador show reductions in sales of some unhealthy food groups one year after implementation $^{(22)}$. In South Korea, the traffic light FOP nutrition labelling system in place applies only for specific children's foods (e.g. snacks) ${ }^{(6)}$.

\section{Summary indicator front-of-package nutrition labelling}

The first summary FOP nutrition labelling system that was developed was the Health Star Ratings by Food Standards Australia New Zealand. The Health Star Ratings system was implemented in 2014 in Australia and New Zealand on a voluntary basis, with products receiving from half a star up to 5 stars dependent on healthfulness defined by negative as well as positive components. Although implementation of the system is slow, with only $5 \%$ of the packaged foods in New Zealand carrying Health Star Ratings as of 2016, there are some positive impacts on product reformulation when comparing products with stars and those without stars in the same product categories $^{(23)}$. In 2017, France developed and implemented a similar voluntary system with five categories, using colour coding and letters (from A to E) that are used to summarize the healthfulness of products rather than a star-based system (Table 2) ${ }^{(24)}$.

\section{Warning labels}

Warning labels that denote foods that are high in certain critical nutrients are another type of FOP nutrition labelling system to be introduced into legislative frameworks. Finland was the first country introducing a warning label for excessive sodium content in some food products in the early $1990 s^{(25,26)}$. In 2016, Chile was the first country to require 'high in' symbols for products that exceed limits for three critical nutrients (sodium, saturated fats, total sugars) and total energy (kilocalories). The same Chilean Law of Food Labelling and Advertising includes the prohibition of marketing foods that qualify for these FOP labels to children under 14 years old, as well as their sale on primary school premises ${ }^{(27)}$. Canada, Israel and Peru are all in the process of developing a similar system ${ }^{(28-30)}$. In contrast to Chile, Canada is proposing to set limits per serving rather than per $100 \mathrm{~g}$ and does not include energy (Table 2$)^{(28)}$. Additionally, FOP health warnings describing potential negative consequences of consuming categories of food, such as sugarsweetened beverages, have been proposed in the USA, but have not been successfully implemented to date ${ }^{(31)}$.

\section{Lessons learnt and recommendations for further research}

The increased uptake of FOP nutrition labelling interventions implemented by governments shows both increasing political and societal acceptability of FOP nutrition 


\begin{tabular}{|c|c|c|c|c|c|c|c|c|}
\hline Type & Name/Symbol & Display & Countries & Mandatory & Nutrients included & $\begin{array}{l}\text { Ingredients } \\
\text { included }\end{array}$ & Limits & Units \\
\hline Logo & Keyhole & Logo & $\begin{array}{l}\text { Norway, } \\
\text { Sweden, } \\
\text { Denmark, } \\
\text { Iceland, } \\
\text { Lithuania }\end{array}$ & No & $\begin{array}{l}\text { Saturated fat, total } \\
\text { sugar, sodium }\end{array}$ & Fibre & $\begin{array}{l}\text { Nutrient criteria for } 25 \text { different } \\
\text { food groups }\end{array}$ & $100 \mathrm{~g} / \mathrm{ml}$ \\
\hline Logo & Choices Programme & Logo & $\begin{array}{l}\text { Netherlands, } \\
\text { Belgium, } \\
\text { Poland, } \\
\text { Czech } \\
\text { Republic, } \\
\text { Mexico }\end{array}$ & No & $\begin{array}{l}\text { Saturated fat, trans } \\
\text { fatty acids, added } \\
\text { sugar, sodium, } \\
\text { energy }\end{array}$ & Fibre & $\begin{array}{l}\text { The international criteria are the } \\
\text { blueprint for national criteria; there } \\
\text { are } 9 \text { basic and } 6 \text { non basic } \\
\text { product groups with nutrient } \\
\text { criteria }\end{array}$ & $\begin{array}{l}100 \mathrm{~g} / \mathrm{ml} \text { or } \\
\text { per serving } \\
\text { (for } \\
\text { energy) }\end{array}$ \\
\hline Logo & $\begin{array}{l}\text { Healthier Choices } \\
(-3) \quad 3\end{array}$ & Logo & Singapore & No & $\begin{array}{l}\text { Total fat, saturated } \\
\text { fat, trans fat, } \\
\text { sodium, total } \\
\text { sugar, calcium }\end{array}$ & Fibre, wholegrain & $\begin{array}{l}\text { Nutrient criteria exist for }>60 \text { sub } \\
\text { categories of foods and } \\
\text { beverages. At least } 20 \text { or } 25 \% \\
\text { more or less of the nutrient/ } \\
\text { ingredient needed. }\end{array}$ & $\%$ Limits \\
\hline Logo & & Logo & Thailand & No & $\begin{array}{l}\text { Sodium, total sugar, } \\
\text { energy, total fat, } \\
\text { saturated fat, } \\
\text { protein, calcium, } \\
\text { iron }\end{array}$ & Fibre & $\begin{array}{l}\text { Beverages, sauces and condiments, } \\
\text { dairy products, ready meals, } \\
\text { instant food and snacks. Point } \\
\text { system in six categories from } \\
\text { worst }(0) \text { to best (5) }\end{array}$ & $\begin{array}{l}100 \mathrm{~g} / \mathrm{ml} \text { and } \\
\text { per serving }\end{array}$ \\
\hline Logo & Healthie & Logo & Brunei & No & $\begin{array}{l}\text { Total fat, saturated } \\
\text { fat, sodium, sugar, } \\
\text { calcium }\end{array}$ & Fibre & $\begin{array}{l}\text { Nutrient criteria exist for }>60 \text { sub } \\
\text { categories of foods and beverages }\end{array}$ & $100 \mathrm{~g} / \mathrm{ml}$ \\
\hline Logo & $\begin{array}{l}\text { Healthier Choices } \\
\text { Symbol not given } \\
\text { since not finalized }\end{array}$ & Logo & Malaysia & No & $\begin{array}{l}\text { Total fat, sugar, } \\
\text { sodium, trans fat, } \\
\text { energy }\end{array}$ & Fibre & $\begin{array}{l}\text { Nutrient criteria exist for } 42 \text { sub } \\
\text { categories of foods and beverages }\end{array}$ & $100 \mathrm{~g} / \mathrm{ml}$ \\
\hline
\end{tabular}




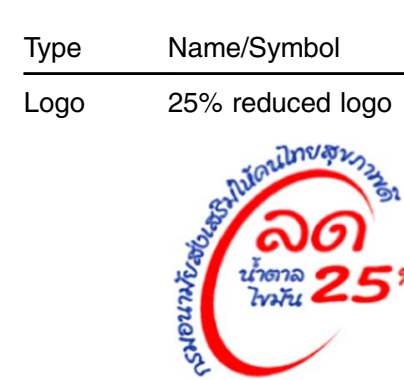

Traffic

Traffic lights

lights

\section{1...}

Mandatory

No

gredients

Logo

Thailand

Sugar, fat, sodium

None

Limits

Units

$25 \%$ lower sugar, fat and/or sodium \% Limits after reformulation snacks: fat (low $<3 \mathrm{~g}$, medium

\section{Traffic \\ Traffic lights \\ lights

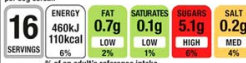

Traffic Traffic lights

lights

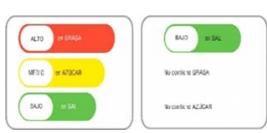
for each critical

nutrient

South Korea

No
Red/Amber/Green for each critical nutrient

UK

Red/Amber/Green Ecuador
for each critical
nutrient

nutrient
Yes

Fats, sugar, salt

None
Total fat, saturated None fat, total sugar,

sodium

Energy, fat,

saturated fat, total sugar, salt
For certain children's foods like 3-9 g, high $>9 \mathrm{~g}$ ); saturated fat (low $<1.5 \mathrm{~g}, 1.5-4 \mathrm{~g},>4 \mathrm{~g}$ ), sodium (low $<120 \mathrm{mg}$, medium $120-300 \mathrm{mg}$ high $>300 \mathrm{mg}$ ), sugar (low $<3 \mathrm{~g}$, medium $3-17 \mathrm{~g}$, high $>17 \mathrm{~g}$ )

Fat (low: $\leq 3.0 \mathrm{~g} / 100 \mathrm{~g}$; medium $>3.0 \mathrm{~g}$ to $\leq 17.5 \mathrm{~g} / 100 \mathrm{~g}$; high:

$>17.5 \mathrm{~g} / 100 \mathrm{~g}$ ) Saturated fat (low: $\leq 1.5 \mathrm{~g} / 100 \mathrm{~g}$; medium: $>1.5 \mathrm{~g}$ to $\leq 5.0 \mathrm{~g} / 100 \mathrm{~g}$; high: $>5.0 \mathrm{~g} / 100 \mathrm{~g}$ ) total sugar (low: $\leq 5.0 \mathrm{~g} / 100 \mathrm{~g}$; medium: $>5.0 \mathrm{~g}$ to $\leq 22.5 \mathrm{~g} / 100 \mathrm{~g}$ high: $>22.5 \mathrm{~g} / 100 \mathrm{~g}$ ) salt (low: $\leq 0.3 \mathrm{~g} / 100 \mathrm{~g}$ : medium: $>0.3 \mathrm{~g}$ to $\leq 1.5 \mathrm{~g} / 100 \mathrm{~g}$; high: $>1.5 \mathrm{~g} / 100 \mathrm{~g}$ )

Total fat (low: $\leq 3 \mathrm{~g} / 100 \mathrm{~g}$ or $1.5 \mathrm{~g} /$ $100 \mathrm{ml}$; medium: $>3$ and $<20 \mathrm{~g} /$ $100 \mathrm{~g}$ or $>1.5$ and $<10 \mathrm{~g} / 100 \mathrm{ml}$; high $(\geq 20 \mathrm{~g} / 100 \mathrm{~g}$ or $\geq 10 \mathrm{~g} / 100 \mathrm{ml})$ Total sugars (low: $\leq 5 \mathrm{~g} / 100 \mathrm{~g}$ or $2.5 \mathrm{~g} / 100 \mathrm{ml}$; medium: $>5$ and $<15 \mathrm{~g} / 100 \mathrm{~g}$ or $>2.5$ and $<7.5 \mathrm{~g} /$ $100 \mathrm{~g}$; high ( $\geq 15 \mathrm{~g} / 100 \mathrm{~g}$ or $\geq 7.5 \mathrm{~g} /$ $100 \mathrm{ml}$ ) Sodium (low: $\leq 120 \mathrm{mg}$ $100 \mathrm{~g} / \mathrm{ml}$; medium: $>120$ and $<600 \mathrm{mg} / 100 \mathrm{~g} / \mathrm{ml}$; high $(\geq 600 \mathrm{mg} /$ $100 \mathrm{~g} / \mathrm{ml}$ )
Per serving of stated size

size




\begin{tabular}{|c|c|c|c|c|c|c|c|c|}
\hline Type & Name/Symbol & Display & Countries & Mandatory & Nutrients included & $\begin{array}{l}\text { Ingredients } \\
\text { included }\end{array}$ & Limits & Units \\
\hline $\begin{array}{l}\text { Summary } \\
\text { system }\end{array}$ & Health Star Ratings & $\begin{array}{l}1 / 2 \text { star (least } \\
\text { healthy) to } 5 \text { stars } \\
\text { (most healthy) }\end{array}$ & $\begin{array}{l}\text { Australia, } \\
\text { New Zealand }\end{array}$ & No & $\begin{array}{l}\text { Energy, saturated } \\
\text { fat, sodium, total } \\
\text { sugar, protein }\end{array}$ & $\begin{array}{l}\text { Fibre, fruits and } \\
\text { vegetables, nuts } \\
\text { and legumes }\end{array}$ & $\begin{array}{l}\text { Calculations of points for each of } \\
\text { the nutrients of concern and } \\
\text { ingredients }\end{array}$ & $100 \mathrm{~g} / \mathrm{ml}$ \\
\hline $\begin{array}{c}\text { Summary } \\
\text { system }\end{array}$ & Nutriscore & $\begin{array}{l}\mathrm{A}, \mathrm{B}, \mathrm{C}, \mathrm{D}, \mathrm{E} \\
\text { according to } \\
\text { healthiness with } \mathrm{A} \\
\text { the most healthy }\end{array}$ & France & No & $\begin{array}{l}\text { Energy, saturated } \\
\text { fat, total sugar, } \\
\text { sodium, proteins }\end{array}$ & $\begin{array}{l}\text { Fibre, fruits and } \\
\text { vegetables }\end{array}$ & $\begin{array}{l}\text { Calculations of points for each of } \\
\text { the nutrients of concern and } \\
\text { ingredients }\end{array}$ & $100 \mathrm{~g} / \mathrm{ml}$ \\
\hline $\begin{array}{c}\text { Warning } \\
\text { labels }\end{array}$ & Warning labels & Logo & Finland & Yes & Salt & None & $\begin{array}{l}\text { Specified by food group; including } \\
\text { all food groups that make a } \\
\text { substantial contribution to salt } \\
\text { intake in Finland, e.g. label } \\
\text { required when } \geq 1.1 \% \text { for bread, } \\
\geq 2.0 \% \text { for sausages, } \geq 2.2 \% \text { for } \\
\text { cold meat cuts, } \geq 2.0 \% \text { for fish } \\
\text { products, } \geq 1.4 \% \text { for cheese, } \\
\geq 1.2 \% \text { for ready meals and } \geq 1.4 \% \\
\text { for breakfast cereals or crisp } \\
\text { bread. }\end{array}$ & $\%$ Limits \\
\hline $\begin{array}{c}\text { Warning } \\
\text { labels }\end{array}$ & $\begin{array}{l}\text { Warning labels } \\
\text { Symbol says "Should } \\
\text { consume in small } \\
\text { amounts and exercise } \\
\text { for better health" }\end{array}$ & Text & Thailand & Yes & $\mathrm{N} / \mathrm{A}$ & $\mathrm{N} / \mathrm{A}$ & Including 5 categories of snack food & $\mathrm{N} / \mathrm{A}$ \\
\hline $\begin{array}{c}\text { Warning } \\
\text { labels }\end{array}$ & Warning labels & $\begin{array}{l}\text { Black warning label } \\
\text { for each critical } \\
\text { nutrient }\end{array}$ & Chile & Yes & $\begin{array}{l}\text { Energy, saturated } \\
\text { fat, sodium, total } \\
\text { sugar }\end{array}$ & None & $\begin{array}{l}\text { Current (not final) limits: calories } \\
\text { ( } 275 / 100 \mathrm{~g} \text { or } 70 / 100 \mathrm{ml}) \text {; } \\
\text { saturated fat }(4 \mathrm{~g} / 100 \mathrm{~g} \text { or } 3 \mathrm{~g} / \\
100 \mathrm{ml}) \text {; total sugar }(10 \mathrm{~g} / 100 \mathrm{~g} \text { or } \\
5 \mathrm{~g} / 100 \mathrm{ml}) \text {; sodium }(400 \mathrm{mg} / 100 \mathrm{~g} \\
\text { or } 100 \mathrm{mg} / 100 \mathrm{ml})\end{array}$ & $100 \mathrm{~g} / \mathrm{ml}$ \\
\hline $\begin{array}{c}\text { Warning } \\
\text { labels }\end{array}$ & $\begin{array}{l}\text { Warning labels } \\
\text { Symbol not given } \\
\text { since not finalized }\end{array}$ & $\begin{array}{l}\text { Red Warning label } \\
\text { for each critical } \\
\text { nutrient }\end{array}$ & Israel & Yes & $\begin{array}{l}\text { Sodium, sugar, } \\
\text { saturated fat }\end{array}$ & None & $\begin{array}{l}\text { Sodium }(>800 \mathrm{mg} / 100 \mathrm{~g}) \text {, total sugar } \\
(>22.5 \mathrm{~g} / 100 \mathrm{~g}) \text { and saturated fat } \\
(>6 \mathrm{~g} / 100 \mathrm{~g})\end{array}$ & $100 \mathrm{~g} / \mathrm{ml}$ \\
\hline
\end{tabular}


labelling. The action by Codex in formally considering global guidelines for FOP nutrition labelling is also an important step forward. Global momentum is increasing for FOP nutrition labelling that inherently motivates countries to act, such as is the case for taxes on sugarsweetened beverages ${ }^{(32)}$. While the rate of policy implementation or consideration is concomitant with the increasing amount of research being conducted in this field, many knowledge gaps remain.

First, while it is well established that interpretive labels are more likely to have an impact on consumer understanding and behaviour than reductive systems alone, less is known about the relative effectiveness or superiority of the various types of interpretive FOP nutrition labelling systems $^{(33-36)}$. Consumer research on FOP nutrition labelling has largely examined health logos and traffic light symbols and, to a lesser extent, Health Star Ratings ${ }^{(37,38)}$. Given the recent introduction of 'high in' FOP nutrition labelling into the policy sphere, more research is needed to examine this labelling scheme, as most of this research is limited to South American contexts ${ }^{(37,39,40)}$. The various FOP nutrition labelling systems support different policy objectives. Therefore, evidence of the comparative impact of these systems on various outcomes, including consumer behaviour and industry reformulation, is warranted. The impact of FOP nutrition labelling systems on reformulation deserves more attention as early results from New Zealand show some positive impact for the Health Star Ratings ${ }^{(23)}$; however, the volume of evidence of the impact of government-initiated FOP nutrition labelling schemes on food reformulation is scarce ${ }^{(23,41,42)}$. There is additional evidence, from voluntary FOP nutrition labelling programmes developed by non-governmental organizations, that FOP nutrition labelling has had positive impacts on the food supply ${ }^{(43-45)}$. Taken together, as more government-sponsored FOP nutrition labelling systems are implemented there is an evident need for more research on how these systems impact industry behaviour, which may subsequently impact consumer behaviour.

Second, limited literature has examined label characteristics that relate to salience, specifically the necessary size of labels, the colour of labels, or the placement of labels on food packages ${ }^{(40,46)}$. Literature from tobacco warning labels has identified these as key characteristics that can influence consumer likelihood of noticing label information and the strength of message portrayed to consumers; this deserves additional attention in the packaged food field ${ }^{(47)}$. The above characteristics are particularly important to policy makers in helping to establish detailed regulations for FOP nutrition labelling requirements.

Third, as previously mentioned above, the foundational concept of FOP nutrition labelling is the ability of these schemes to communicate information in a simple, understandable format to individuals with low literacy levels who face greater challenges understanding complex, numeric information often on the back of food packages. 
While the differential effect of FOP nutrition labelling along sociodemographic and literacy lines is starting to be incorporated into the literature ${ }^{(48-50)}$, there is still a lack of understanding of who benefits from FOP nutrition labelling policies and what these policies will do to existing health inequities. Recently, Backholer and colleagues have come up with a framework for doing so, and this deserves additional attention ${ }^{(51)}$.

Fourth, there is a lack of research that examines FOP nutrition labelling use in real-world settings, with most research being conducted in online environments ${ }^{(48)}$. Online studies can provide insight into the impact of FOP nutrition labelling on consumer understanding and perceived willingness to pay or intent to purchase. Yet, the online setting is limited in its ability to require consumers to factor in issues known to influence purchasing habits significantly, such as the time dedicated to each purchasing decision, brand loyalty and taste preferences. Online research is also limited in its ability to capture how understanding and use of FOP nutrition labelling may change over time, or how supplemental education campaigns (by government, industry or both) may support consumer understanding. The paucity of evidence of the public health impacts, especially regarding the real-world impact on consumer purchases and dietary habits and industry actions, is largely indicative of the short amount of time that has lapsed since the government-sponsored creation and implementation of FOP nutrition labelling. Rigorous quasi-experimental studies with objective data such as sales data, and cross-country comparisons examining the FOP nutrition labelling policies implemented to date, have the potential to fill this evidence gap.

Finally, there are important policy decisions to be made regarding the implementation of voluntary governmentendorsed FOP nutrition labelling policies (such as the Health Star Ratings in Australia and New Zealand) $v$. mandatory policies (such as those implemented in Chile and Ecuador, among others). Voluntary guidelines or schemes do not require labels on all packages, which may bias consumer perceptions towards products with labels that are equally, or potentially less, healthful than products with no labels, as has been demonstrated in previous research $^{(52)}$. In addition, evidence to date suggests that the uptake of voluntary FOP nutrition labelling is slow, as demonstrated in New Zealand where only $5 \%$ of products carry the Health Star Ratings ${ }^{(23)}$. Finally, decisions regarding mandatory or voluntary implementation may also influence the amount of opposition from industry with regard to FOP nutrition labelling policy. Preliminary evidence from Canada and Chile suggests that there is a high level of opposition to mandatory warning label policy ${ }^{(53,54)}$. Similarly, while evidence from the EU suggests that voluntary schemes are more palatable to industry stakeholders and less likely to be lobbied, EU countries currently can only implement voluntary schemes by EU regulation $^{(55)}$.

\section{Conclusion}

An increasing variety of FOP nutrition labelling systems have been implemented to date globally with two common goals: (i) to communicate complex information to consumers in an easily understood, standardized format, to guide, inform and shape consumer food choices and behaviours; and (ii) to stimulate industry reformulation. Few FOP nutrition labelling systems are currently mandatory and therefore evidence of the real-life impact of mandatory FOP nutrition labelling systems on consumer behaviour and industry reformulation is limited. The potential impact of FOP nutrition labelling on reducing nutrition inequalities is uncertain and it is therefore important to evaluate the ability of FOP nutrition labelling schemes to effectively communicate information to different target groups. The published studies to date that include voluntary FOP nutrition labelling suggest that the impact of FOP nutrition labelling on industry reformulation may have greater potential to affect all consumers, independent of sociodemographic characteristics, compared with impacts on consumer behaviour that are often influenced by sociodemographic characteristics. As most of the mandatory FOP nutrition labelling schemes have been implemented only over the past 5 years, it is anticipated that more scientific evidence will become available that will further accelerate the uptake of this important policy option on a global scale.

\section{Rebecca Kanter ${ }^{1}$, Lana Vanderlee ${ }^{2}$ and Stefanie Vandevijvere ${ }^{3}$}

${ }^{1}$ Department of Nutrition Faculty of Medicine University of Chile Independencia 1027, Postal Code 8380453 Santiago, Chile

Email: rkanter@med.uchile.cl

${ }^{2}$ Department of Nutritional Sciences Faculty of Medicine University of Toronto Toronto, Ontario, Canada

${ }^{3}$ Department of Epidemiology and Biostatistics School of Population Health

University of Auckland Auckland, New Zealand

\section{References}

1. Feunekes GIJ, Gortemaker IA, Willems AA et al. (2008) Front-of-pack nutrition labelling: testing effectiveness of different nutrition labelling formats front-of-pack in four European countries. Appetite 50, 57-70.

2. Pomeranz JL (2011) Front-of-package food and beverage labeling. Am J Prev Med 40, 382-385.

3. Hieke S \& Taylor CR (2012) A critical review of the literature on nutritional labeling. J Consum Aff 46, 120-156. 
4. Kasapila W \& Shaarani SM (2016) Legislation - impact and trends in nutrition labeling: a global overview. Crit Rev Food Sci Nutr 56, 56-64.

5. Schermel A, Emrich TE, Arcand J et al. (2013) Nutrition marketing on processed food packages in Canada: 2010 Food Label Information Program. Appl Physiol Nutr Metab 38, 666-672.

6. World Cancer Research Fund International (2017) NOURISHING framework: Nutrition label standards and regulations on the use of claims and implied claims on food. http://www.wcrf.org/sites/default/files/1_Nutrition_labels_ Oct2017_0.pdf (accessed November 2017).

7. Brownell KD \& Koplan JP (2011) Front-of-package nutrition labeling - an abuse of trust by the food industry? $N$ Engl J Med 364, 2373-2375.

8. Pan American Health Organization (2015) Ultra-Processed Food and Drink Products in Latin America: Trends, Impact on Obesity, Policy Implications. Washington, DC: PAHO.

9. Moodie R, Stuckler D, Monteiro C et al. (2013) Profits and pandemics: prevention of harmful effects of tobacco, alcohol, and ultra-processed food and drink industries. Lancet 381, 670-679.

10. Institute of Medicine (2010) Examination of Front-ofPackage Nutrition Rating Systems and Symbols: Phase I Report. Washington, DC: The National Academies Press.

11. World Health Organization (2004) Global Strategy on Diet, Physical Activity and Health. Geneva: WHO.

12. World Health Organization (2013) Global Action Plan for the Prevention and Control of Noncommunicable Diseases, 2013-2020. Geneva: WHO.

13. World Health Organization (2016) Report of the Commission on Ending Childhood Obesity. Geneva: WHO.

14. World Health Organization (2013) Joint FAO/WHO workshop on Front-of-Pack Nutrition Labelling. http://www.who. int/nutrition/events/2013_FAO_WHO_workshop_frontofpack_ nutritionlabelling/en/ (accessed November 2017).

15. World Health Organization (2015) Technical meeting on nutrition labelling for promoting healthy diets. http://www. who.int/nutrition/events/2015_meeting_nutrition_labelling_ diet 9to11dec/en/ (accessed November 2017).

16. Institute of Medicine (2012) Front-of-Package Nutrition Rating Systems and Symbols: Promoting Healthier Choices. Washington, DC: The National Academies Press.

17. Codex Alimentarius Commission (2010) General Standard for the Labelling of Prepackaged Foods. Rome: FAO.

18. Codex Alimentarius Commission (2016) Joint FAO/WHO Food Standards Programme. Codex Committee on Food Labelling. Forty-third Session, Ottawa, Ontario, Canada, 9-13 May 2016. Proposal for New Work Concerning a Global Standard for Front of Pack Interpretive Nutrition Labelling. http://www.fao.org/fao-who-codexalimentarius/ sh-proxy/en/?lnk=1\&url=https $\% 253 \mathrm{~A} \% 252 \mathrm{~F} \% 252 \mathrm{Fw}$ orkspace. fao.org\%252Fsites $\% 252$ Fcodex $\% 252$ FMeetings $\% 252$ FCX-714-43 \%252FCRD\%252Ffl43_CRD17x.pdf (accessed January 2018).

19. Thow AM, Jones A, Hawkes C et al. (2017) Nutrition labelling is a trade policy issue: lessons from an analysis of specific trade concerns at the World Trade Organization. Health Promot Int. Published online: 12 January 2017. doi: 10.1093/heapro/daw109.

20. Choices Programme (2017) The Choices Programme. https:// www.choicesprogramme.org/ (accessed November 2017).

21. Rayner M, Wood A, Lawrence M et al. (2013) Monitoring the health-related labelling of foods and non-alcoholic beverages in retail settings. Obes Rev 14, Suppl. 1, 70-81.

22. Díaz AA, Veliz PM, Rivas-Mariño G et al. (2017) Etiquetado de alimentos en Ecuador: implementación, resultados y acciones pendientes. Rev Panam Salud Publica 41, e54.

23. Mhurchu CN, Eyles H \& Choi Y (2017) Effects of a voluntary front-of-pack nutrition labelling system on packaged food reformulation: the Health Star Rating System in New Zealand. Nutrients 9, E918.
24. Julia C, Peneau S, Buscail C et al. (2017) Perception of different formats of front-of-pack nutrition labels according to sociodemographic, lifestyle and dietary factors in a French population: cross-sectional study among the NutriNet-Sante cohort participants. BMJ Open 7, e016108.

25. Pietinen P, Valsta LM, Hirvonen T et al. (2008) Labelling the salt content in foods: a useful tool in reducing sodium intake in Finland. Public Health Nutr 11, 335-340.

26. Pietinen P, Männistö S, Valsta LM et al. (2010) Nutrition policy in Finland. Public Health Nutr 13, 901-906.

27. Corvalán C, Reyes M, Garmendia ML et al. (2013) Structural responses to the obesity and non-communicable diseases epidemic: the Chilean Law of Food Labeling and Advertising. Obes Rev 14, Suppl. 2, 79-87.

28. Health Canada (2017) Consultation on front-of-package nutrition labelling. https://www.canada.ca/en/healthcanada/programs/front-of-package-nutrition-labelling.html (accessed November 2017).

29. Dovrat-Meseritz A (2016) Israeli food giants angered as Ministry demands labels for unhealthy products in 6 months. https://www.haaretz.com/israel-news/business/ 1.752915 (accessed November 2017).

30. FAS Lima (2017) Peru Publishes Warning Manual for Processed Product Food Labels. https://www.fas.usda. gov/data/peru-peru-publishes-warning-manual-processedproduct-food-labels (accessed January 2018).

31. Popova L (2016) Sugar-sweetened beverage warning labels: lessons learned from the tobacco industry. I Calif Dent Assoc 44, 633-640.

32. Backholer K, Blake M \& Vandevijvere S (2016) Have we reached a tipping point for sugar-sweetened beverage taxes? Public Health Nutr 19, 3057-3061.

33. Hawley KL, Roberto CA, Bragg MA et al. (2013) The science on front-of-package food labels. Public Health Nutr 16, 430-439.

34. Maubach N, Hoek J \& Mather D (2014) Interpretive front-ofpack nutrition labels. Comparing competing recommendations. Appetite 82, 67-77.

35. Hersey JC, Wohlgenant KC, Arsenault JE et al. (2013) Effects of front-of-package and shelf nutrition labeling systems on consumers. Nutr Rev 71, 1-14.

36. Cecchini M \& Warin L (2016) Impact of food labelling systems on food choices and eating behaviours: a systematic review and meta-analysis of randomized studies. Obes Rev 17, 201-210.

37. Volkova E \& Mhurchu CN (2015) The influence of nutrition labeling and point-of-purchase information on food behaviours. Curr Obes Rep 4, 19-29.

38. Arrúa A, Curutchet MR, Rey N et al. (2017) Impact of frontof-pack nutrition information and label design on children's choice of two snack foods: comparison of warnings and the traffic-light system. Appetite 116, 139-146.

39. Arrúa A, Machín L, Curutchet MR et al. (2017) Warnings as a directive front-of-pack nutrition labelling scheme: comparison with the Guideline Daily Amount and trafficlight systems. Public Health Nutr 20, 2308-2317.

40. Cabrera M, Machín L, Arrúa A et al. (2017) Nutrition warnings as front-of-pack labels: influence of design features on healthfulness perception and attentional capture. Public Health Nutr 20, 3360-3371.

41. Wyness LA, Butriss JL \& Stanner SA (2012) Reducing the population's sodium intake: the UK Food Standards Agency's salt reduction programme. Public Health Nutr 15, 254-261.

42. Mandle J, Tugendhaft A, Michalow J et al. (2015) Nutrition labelling: a review of research on consumer and industry response in the global South. Glob Health Action $\mathbf{8}$, 25912.

43. Vyth EL, Steenhuis IH, Roodenburg AJ et al. (2010) Front-ofpack nutrition label stimulates healthier product development: a quantitative analysis. Int J Behav Nutr Phys Act 7, 65. 
44. Thomson RK, McLean RM, Ning SX et al. (2016) Tick frontof-pack label has a positive nutritional impact on foods sold in New Zealand. Public Health Nutr 19, 2949-2958.

45. Ning SX, Mainvil LA, Thomson RK et al. (2017) Dietary sodium reduction in New Zealand: influence of the 'Tick' label. Asia Pac J Clin Nutr 26, 1133-1138.

46. Becker MW, Bello NM, Sundar RP et al. (2015) Front of pack labels enhance attention to nutrition information in novel and commercial brands. Food Policy 56, 76-86.

47. Hammond D (2011) Health warning messages on tobacco products: a review. Tob Control 20, 327-337.

48. Watson WL, Kelly B, Hector D et al. (2014) Can front-ofpack labelling schemes guide healthier food choices? Australian shoppers' responses to seven labelling formats. Appetite 72, 90-97.

49. Gorton D, Mhurchu CN, Chen M et al. (2009) Nutrition labels: a survey of use, understanding and preferences among ethnically diverse shoppers in New Zealand. Public Health Nutr 12, 1359-1365.

50. Kelly B, Hughes C, Chapman K et al. (2009) Consumer testing of the acceptability and effectiveness of front-of-pack food labelling systems for the Australian grocery market. Health Promot Int 24, 120-129.

51. Backholer K, Beauchamp A, Ball K et al. (2014) A framework for evaluating the impact of obesity prevention strategies on socioeconomic inequalities in weight. Am J Public Health 104, e43-e50.

52. Talati Z, Pettigrew S, Dixon H et al. (2016) Do health claims and front-of-pack labels lead to a positivity bias in unhealthy foods? Nutrients $\mathbf{8}$, E787.

53. Health Canada (2017) Front-of-Package Nutrition Labelling: September 18 Stakeholder Engagement Meeting. Ottawa: Health Canada.

54. Velasco AR (2016) Chile: new food labeling regulations leave a bitter taste. INTABulletin 71 , issue 6 . https://www. inta.org/INTABulletin/Pages/Chile_7106.aspx (accessed January 2018).

55. EUFIC (2017) Global Update on Nutrition Labelling: The 2017 Edition. Brussels: EUFIC.

56. Hamlin R \& McNeill L (2016) Does the Australasian 'Health Star Rating' front of pack nutritional label system work? Nutrients 8, E327. 